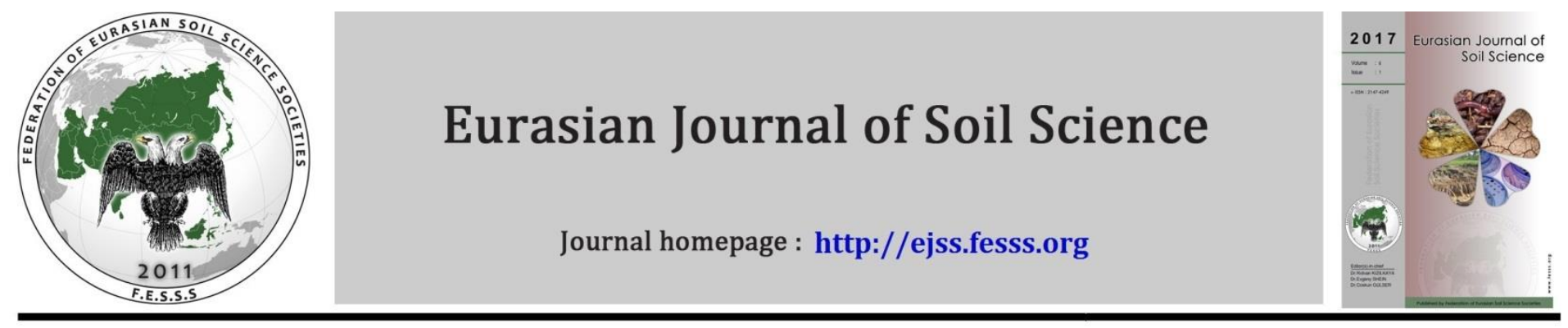

\title{
Soil organic matter content and composition in different pedoclimatic zones of Bulgaria
}

\author{
Biser Hristov *, Ekaterina Filcheva
}

"N. Poushkarov" Institute of Soil Science, Agrotechnology and Plant Protection, Sofia, Bulgaria

\section{Article Info}

Received : 13.05.2016

Accepted : 02.08.2016

\begin{abstract}
The present paper focused on content, quality and composition of soil organic matter in different pedoclimatic zones of Bulgaria. The country has temperate continental climate with Mediterranean influence. There are six combinations of soil temperature and moisture regimes over the territory of Bulgaria, such as Thermic-Xeric, MesicXeric, Mesic-Ustic, Mesic-Udic, Cryic-Udic and Pergelic - Udic. Typical soil types for Bulgaria are Chernozems, Luvisols. Vertisols, Cambisols, Phaeozems, Leptosols, Regosols, Planosols, Umbrisols and etc. Fifteen soil profiles were studied which are representative for the area. The content and composition of organic matter were determined according to the method of Kononova-Belchikova. The purpose of this study is to determine the influence of pedoclimatic conditions over soil organic matter content and composition of various areas with different soil cover, vegetation, management and etc. Grouping soil types in different soil temperature and moisture regimes shows that there are similarities in soil carbon content and composition. Soils developed under cooler and moister conditions accumulate more organic carbon. In such areas the content of organic carbon can reach about 255 t.ha $^{-1}$ in a surface horizon and the type of humus is predominantly Fulvic. Respectively, soils developed under dry and warmer conditions have lower organic carbon content and the type of humus is usually Humic.
\end{abstract}

Keywords: Soil organic matter, soil carbon, pedoclimate, soil temperature, moisture regimes

(C) 2017 Federation of Eurasian Soil Science Societies. All rights reserved

\section{Introduction}

Soils of Bulgaria are developed in different climatic conditions. The country lies between the strongly contrasting temperate continental and Mediterranean climatic zones. Bulgarian mountains and valleys act as barriers or channels for air masses, causing sharp contrasts in weather over relatively short distances. The continental zone is predominant, because continental air masses flow easily into the unobstructed Danubian plain.

Mediterranean influence is spread manly over south parts of the country (Geography of Bulgaria, 2002). Bulgaria is a country with alternation of contrasting seasons. Soils have an annual heating cycle, becoming warm during the summer and then cool to freezing during the winter. The effect on soil is determined by the rates of chemical and biological reactions and evaporation (Shishkov et al., 2014). Climatic conditions have the main impact on vegetation and crop management, which also has influence over soil organic matter content. Soils have the potential to store carbon, in grassland and forest, and particularly in peatlands, through the removal of carbon dioxide during photosynthesis. Soils contain a stock of carbon that is about

\footnotetext{
${ }^{*}$ Corresponding author.

"N. Poushkarov" Institute of Soil Science, Agrotechnology and Plant Protection, Shosse Bankya 7, 1331 Sofia, Bulgaria

Tel.: +359887808397

E-mail address: bisseru@gmail.com

e-ISSN: 2147-4249
} 
twice as large as that in the atmosphere and about three times that in vegetation (Smith et al., 2008). The content of organic carbon in soils is increasingly important topic in recent years in relation to climate change, greenhouse gas emissions associated with carbon emissions into the atmosphere.

\section{Topographic Map of Bulgaria}
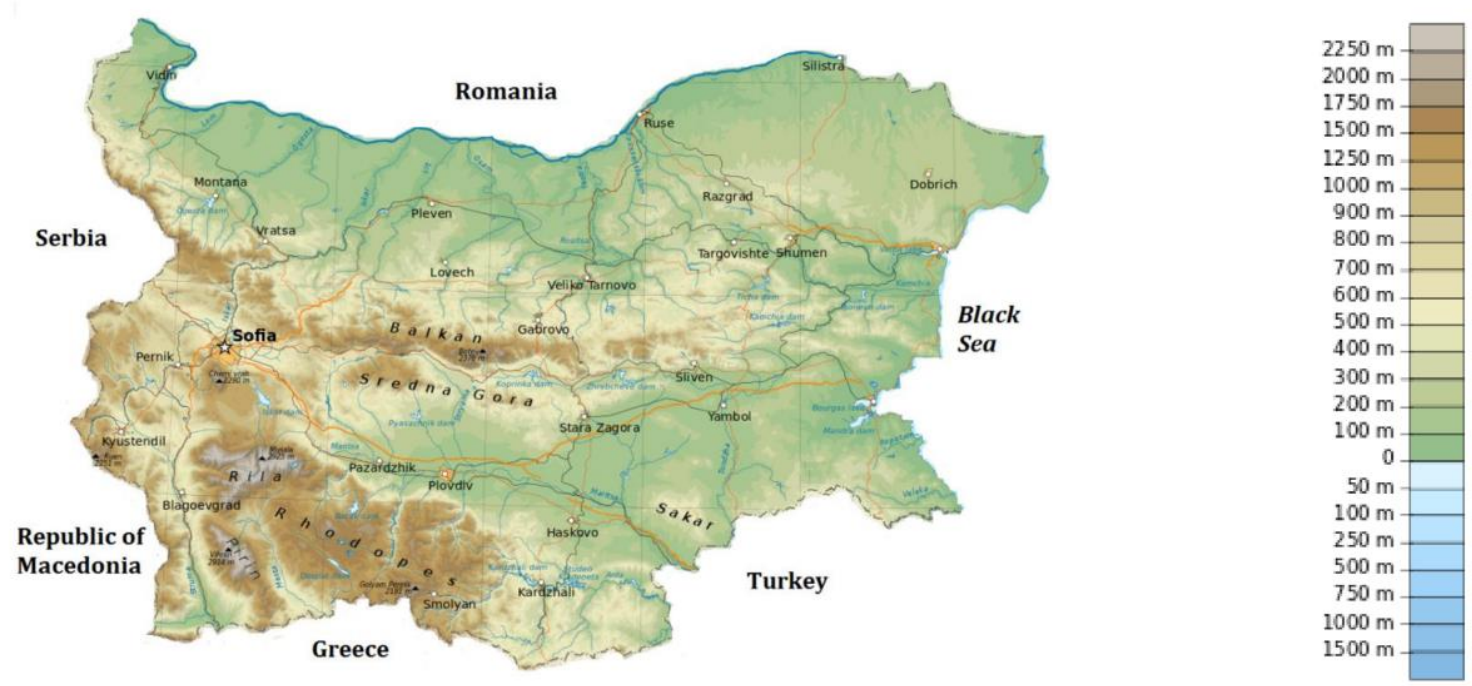

Figure 1. Topographic map of Bulgaria

(https://commons.wikimedia.org/wiki/User:Ikonact)

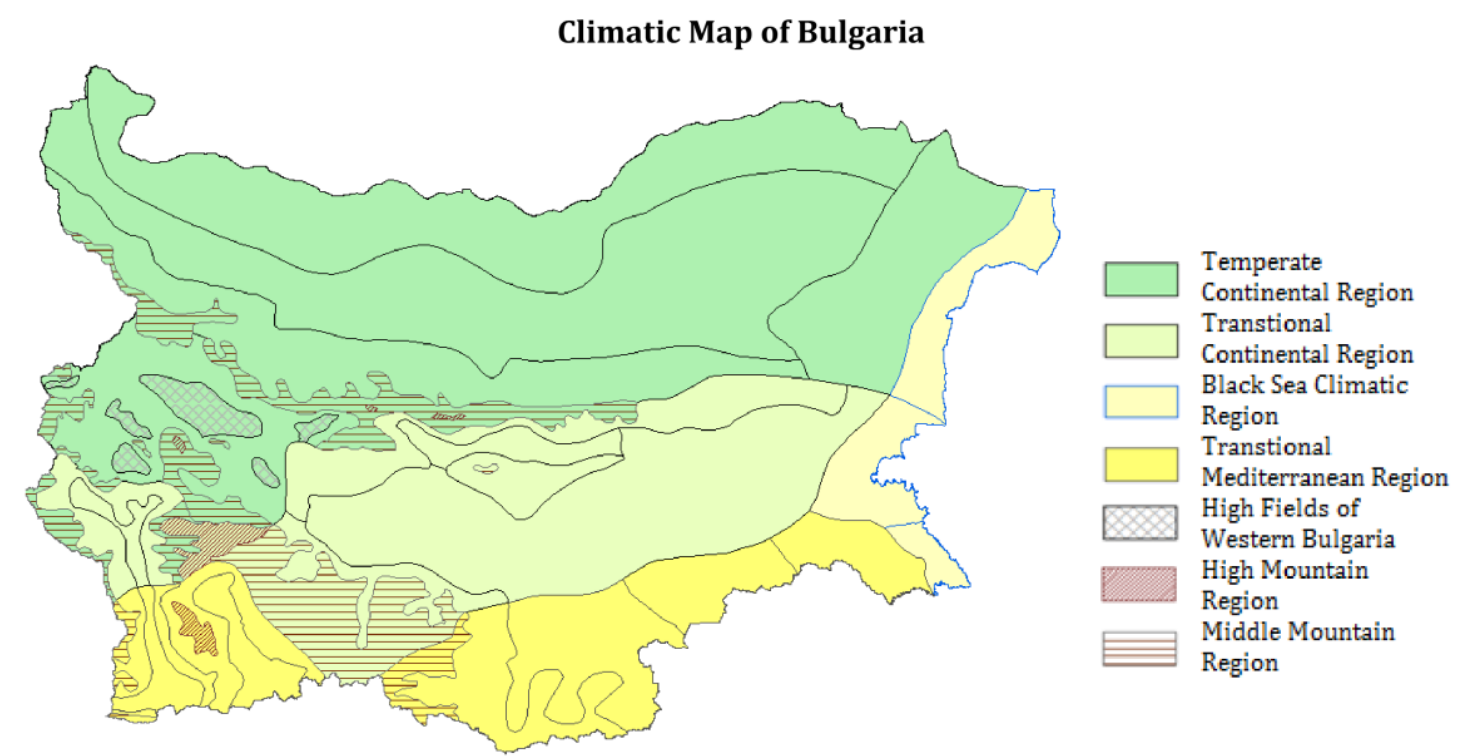

Figure 2. Climatic map of Bulgaria. (Subev et al. (1963) digitized by Dimitrov (2014))

Now we are talking about sequestration of carbon from the atmosphere and holding in the soil to avoid the negative consequences of climate change. The climate is one of the major driving force of soil formation and accumulation of organic carbon (Constatini et al., 2013). Soil climate regimes, expressed via soil moisture and soil temperature regimes, are important in a wide range of applications as soil quality, farming, and ecosystem management. Soils themselves may respond to climate change, leading to both positive and negative effects. Organic carbon in soils is also sensitive to climate change, because this is an interaction between vegetation, climate and parent materials. Soil organic matter is one open dynamic system which is permanently renovated and humus is always in thermodynamic equilibrium with the environmental 
conditions (Schnitzer and Khan, 1972; Stevenson 1994; Orlov, 1985; Krastanov et al., 2003; Filcheva, 2015). The amounts of soil organic $\mathrm{C}$ depend on the relative temperature sensitivities of productivity and soil organic matter decomposition rate. Equations for the temperature dependence of net primary productivity have been widely used, but the temperature dependence of decomposition rate is less clear (Kirschbaum, 1995).

\section{Temperature and Moisture Regimes of Bulgarian Soils}
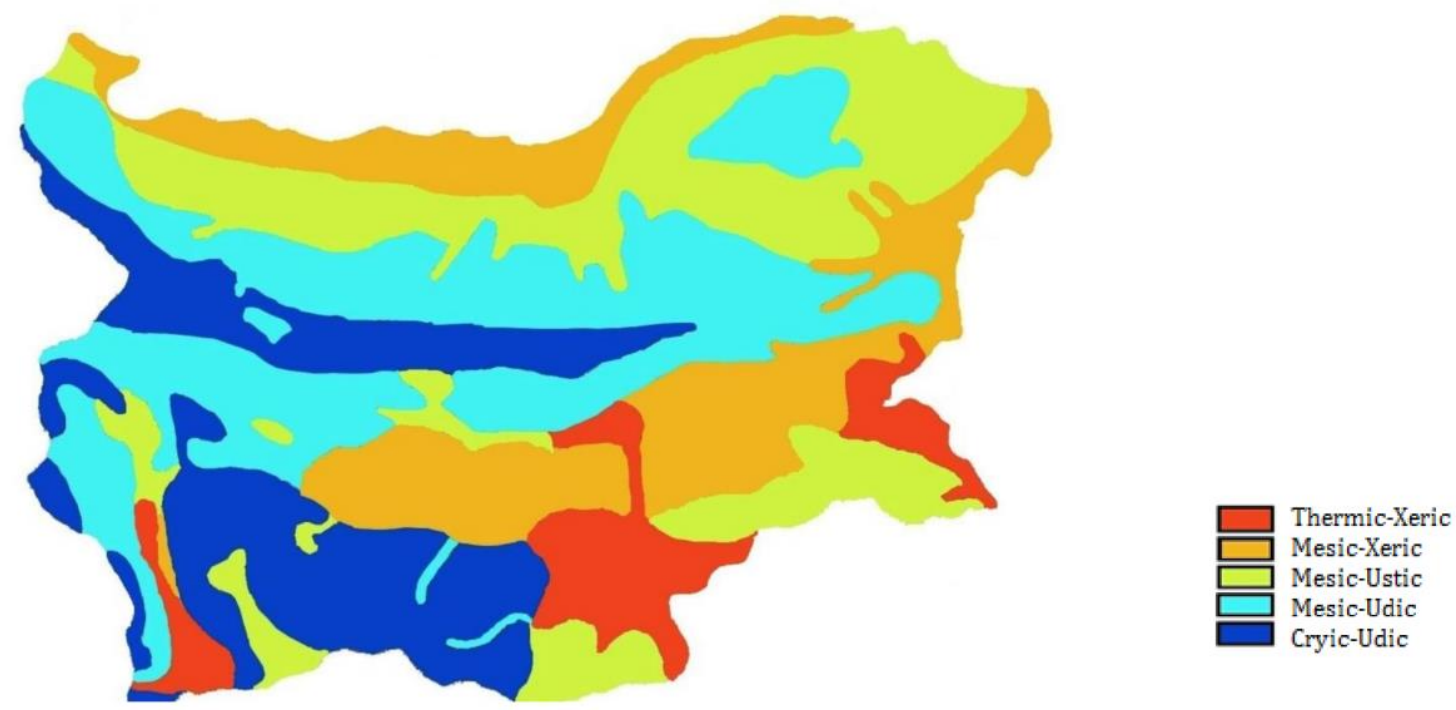

Figure 3. Temperature and moisture regimes of Bulgarian soils. (Boyadjiev, 1989)

The aim of this paper is to focus on influence of different pedoclimatic conditions on soil organic matter content and composition of various areas with different vegetation, management and etc.

\section{Material and Methods}

Five climatic regions are typical for the territory of Bulgaria (Figure 2) - Temperate continental, Transitional continental, Transitional Mediterranean, Black Sea coast, and Mountainous (Subev et al, 1963; Dimitrov, 2014). All these climatic regions have influence over soil temperature and moisture regimes as defined in Soil Taxonomy (Soil Survey Staff, 1999, 2010; FAO, 2006). Boyadjiev (1989) applied the model of Newhall (1972) and identified six different combinations of temperature and moisture regimes over the territory of Bulgaria (Figure 3): Thermic-Xeric, Mesic-Xeric, Mesic-Ustic, Mesic-Udic, Cryic-Udic and Pergelic - Udic. The last one Pergelic - Udic is too small and it is united with Cryic - Udic zone, which is spread mainly on mountainous area of Bulgaria. The Mesic - Udic zone is cover the area of fore-mountains, high fields of central and western Bulgaria and the region of "Ludogorie" of North-East Bulgaria. Soils with Mesic - Ustic regime cover also some regions with lower hilly-mountain relief in South and West Bulgaria. Mesic - Xeric and Thermic- Xeric zones are spread over the lowest and most dry places of Bulgaria, the first one covers northern parts the second one is in the south parts of Bulgaria.

In all these pedoclimatic zones of Bulgaria, typical soil profiles data would be given according to specific soil group of WRB (2014).

Soil organic matter composition was determined by the method of Kononova-Belchikova (Kononova, 1966; Filcheva and Tsadilas, 2002).Total humic and fulvic acids (Cextr.) after extraction with mixed solution of $0.1 \mathrm{M} \mathrm{Na}_{4} \mathrm{P}_{2} \mathrm{O}_{7}$ and $0.1 \mathrm{M} \mathrm{NaOH}$; "free" and $\mathrm{R}_{2} \mathrm{O}_{3}$ bounded humic and fulvic acids $\left(\mathrm{C}_{\mathrm{NaOH}}\right)$ after extraction with $0.1 \mathrm{M} \mathrm{NaOH}$ and the most dynamic, low molecular fraction of organic matter, so called "aggressive" fulvic acids fraction - $1^{\text {a }}$ extracted with $0.05 \mathrm{M} \mathrm{H}_{2} \mathrm{SO}_{4}$, ratio soil:solution=1:20 for the three extractions. Humic and fulvic acids in both extracts $\mathrm{C}_{\mathrm{extr}}$ and $\mathrm{C}_{\mathrm{NaOH}}$ were separated by acidifying the solution with sulfuric acid $(0.5$ M). 

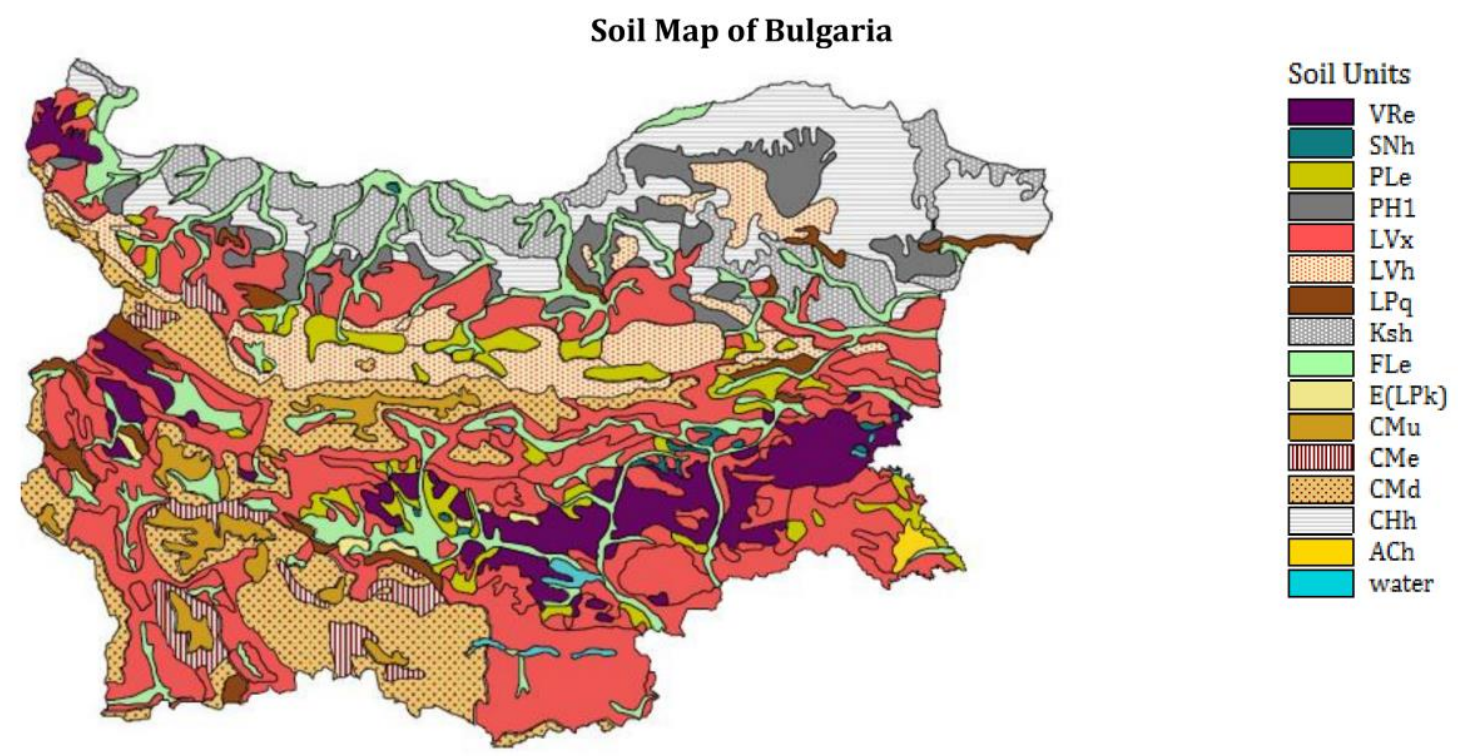

Figure 4. Soil map of Bulgaria. (Kolchakov, 1994), (Soil Units: VRe - Eutric Vertisols; SNh - Haplic Solonetz; PLe - Eutric Planosols; PHl - Luvic Phaeozems; LVx - Chromic Luvisols; LVh - Haplic Luvisols; LPq - Lithic Leptosols; KSh - Haplic Kastanozems; FLe - Eutric Fluvisols ; LPk - Rendzic Leptosols ; CMu - Humic Cambisols; CMe - Eutric Cambisols ; CMd Dystric Cambisols; CHh - Haplic Chernozems; ACh - Haplic Acrisols )

\section{Results and Discussion}

\section{Cryic - Udic}

About $13 \%$ of the territory of Bulgaria has mountainous relief higher than $1000 \mathrm{~m}$ above sea level, which is typical for Balkan region (Geography of Bulgaria, 2002). Cryic - Udic is typical soil temperature and moisture regime for high mountains of Bulgaria, because the temperature is low and soils are almost always wet (Figure 3). Typical soil types here are Umbrisols, Leptosols and Cambisols, according to soil map of Bulgaria (Figure 4). Well known fact is that Umbrisols are soils with a surface accumulation of organic matter with shallow depth, spread in the highest alpine parts of the mountains. The influence of the climate on soil formation is strong because of high humidity, low annual temperature - about $0^{\circ} \mathrm{C}$, and annual precipitation sums of about $900-1000 \mathrm{~mm}$. The organic matter content is high 8-19\% in surface horizon (Shishkov et al., 2014, Andreeva, 2014). According to Artinova (2014) the area of Leptic Umbrisols is about 140000 ha and organic matter stocks are about 255 t.ha- $^{-1}$ in a surface horizon.

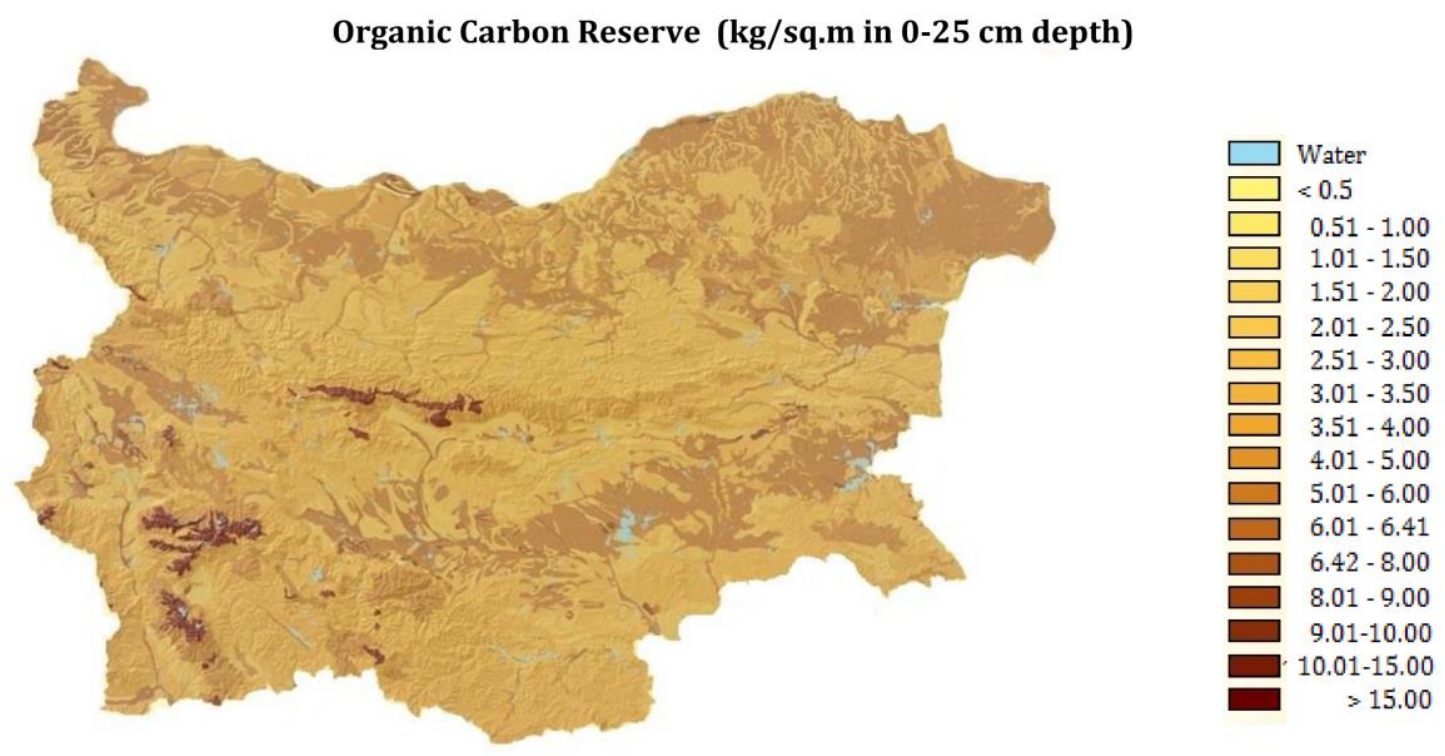

Figure 5. Organic carbon reserve 0 - $25 \mathrm{~cm}$ depth of Bulgarian soils. (Filcheva, 2014) 
Fulvic acids prevail in the humus composition (Table 1). The type of humus is Fulvic - Humic (Ch/Cf 1 - 1.5) and in the alpine parts is Fulvic $(\mathrm{Ch} / \mathrm{Cf}<0.5)$. Fulvic acids are characterized by low molecule condensation. Some amounts of Humic acids may occur at the top of the soil, they are represented by "free" and Humic acids bound with $\mathrm{R}_{2} \mathrm{O}_{3}$ (Filcheva, 2015). The carbon stocks may exceed $15 \mathrm{~kg} / \mathrm{m}^{2}$ in $0-25 \mathrm{~cm}$ layer (Figure 6 ) and the degree of humification is high 20 - $27 \%$ (Artinova, 2014). Other soil types Cambisols and Leptosols have similar properties, especially soils with Umbric horizons, but the organic matter could be lower.

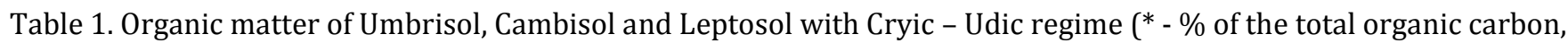
**. $\%$ of the total HA)

\begin{tabular}{|c|c|c|c|c|c|c|c|}
\hline \multirow{2}{*}{$\begin{array}{l}\text { Horizon, } \\
\text { Depth cm }\end{array}$} & \multirow{2}{*}{$\begin{array}{l}\text { Total } \\
\text { Carbon } \\
\text { (C) } \%\end{array}$} & \multicolumn{3}{|c|}{$\begin{array}{c}\text { Org. Carbon } \% \text {-Extracted with } \\
0.1 \mathrm{M} \mathrm{Na} \mathrm{Na}_{2} \mathrm{O}_{7}+0.1 \mathrm{M} \mathrm{NaOH}\end{array}$} & \multirow{2}{*}{$\begin{array}{c}\text { "Free" Humic } \\
\text { acids \% or } \\
\text { bound with } \\
\mathrm{R}_{2} \mathrm{O}_{3}, * *\end{array}$} & \multirow{2}{*}{$\begin{array}{l}\text { Humic acids \% } \\
\text { bound with } \\
\text { Calcium }\left(\mathrm{Ca}^{+2}\right) \text {, } \\
* *\end{array}$} & \multirow[t]{2}{*}{$\mathrm{Ch} / \mathrm{Cf}$} \\
\hline & & $\begin{array}{l}\text { Total } \\
(\%), *\end{array}$ & $\begin{array}{l}\text { Humic acids } \\
(\%),{ }^{*}\end{array}$ & $\begin{array}{c}\text { Fulvic acids } \\
(\%), *\end{array}$ & & & \\
\hline \multicolumn{8}{|c|}{ Profile 1. Haplic Umbrisols - Artinova et al. (1985) (Stara planina- mountain. 1400m.) } \\
\hline Ah $0-19$ & 9.15 & 59.25 & 32.33 & 26.91 & 100 & 0 & 1.2 \\
\hline A2 19-36 & 7.22 & 67.11 & 38.99 & 28.32 & 98.49 & 1.51 & 1.37 \\
\hline \multicolumn{8}{|c|}{ Profile 2. Umbric Cambisols - Artinova et al. (1985) (Stara planina- mountain, 1400m. ) } \\
\hline Ah $0-20$ & 4.33 & 56.97 & 21.07 & 35.89 & 100 & 0 & 0.58 \\
\hline Bw1 20-48 & 1.85 & 66.87 & 9.98 & 57.63 & 100 & 0 & 0.16 \\
\hline Bw2 48-58 & 0.94 & 61.79 & 6.88 & 54.91 & - & - & 0.12 \\
\hline \multicolumn{8}{|c|}{ Profile 3. Umbric Leptosols - (M8-1) Andreeva (2014) (Vitosha mountain, 2290m. ) } \\
\hline Ah $0-20$ & 10.1 & 94.06 & 34.95 & 59.10 & 100 & 0 & 0.59 \\
\hline
\end{tabular}

\section{Mesic - Udic}

Mesic - Udic pedoclimatic zone is spread mainly over foremoutain area, high fields of central and western Bulgaria and Ludogorie region. Typical for these regions: they are covered with forest and the relief is hillymountainous. The main soil types for that zone are Cambisols, Planosols, Stagnosols, Luvisols, Leptosols and Phaeozems that cover the region of Ludogorie. The area is covered manly with forest, the belt of beech form $800 \mathrm{~m}$ to $1500 \mathrm{~m}$ and oak forests from $0-800 \mathrm{~m}$ altitude. Cambisols are the main soil type under forest and on the slope deluvial terrains.

Table 2. Organic matter of Cambisol, Palnosol and Luviosol with Mesic - Udic regime $*^{*}$ - \% of the total organic carbon, ** - \% of the total HA).

\begin{tabular}{|c|c|c|c|c|c|c|c|}
\hline \multirow{2}{*}{$\begin{array}{l}\text { Horizon, } \\
\text { Depth cm }\end{array}$} & \multirow{2}{*}{$\begin{array}{l}\text { Total } \\
\text { Carbon } \\
\text { (C) } \%\end{array}$} & \multicolumn{3}{|c|}{$\begin{array}{c}\text { Org. Carbon\% } \% \text {-Extracted with } \\
0.1 \mathrm{M} \mathrm{Na}{ }_{4} \mathrm{P}_{2} \mathrm{O}_{7}+0.1 \mathrm{M} \mathrm{NaOH}\end{array}$} & \multirow{2}{*}{$\begin{array}{c}\text { Free Humic } \\
\text { acids \% or } \\
\text { bound with } \\
\mathrm{R}_{2} \mathrm{O}_{3}, * *\end{array}$} & \multirow{2}{*}{$\begin{array}{c}\text { Humic acids } \\
\% \text { bound } \\
\text { with Calcium } \\
\left(\mathrm{Ca}^{+2}\right), * *\end{array}$} & \multirow[t]{2}{*}{$\mathrm{Ch} / \mathrm{Cf}$} \\
\hline & & $\begin{array}{l}\text { Total } \\
(\%), *\end{array}$ & $\begin{array}{c}\text { Humic acids } \\
(\%),{ }^{*}\end{array}$ & $\begin{array}{c}\text { Fulvic acids } \\
(\%),{ }^{*}\end{array}$ & & & \\
\hline \multicolumn{8}{|c|}{ Profile 4. Haplic Cambisol -Shishkov et al. (2015) (Sredna gora - mountain, $520 \mathrm{~m}$ ) } \\
\hline Ah $0-10$ & 1.83 & 44.26 & 19.67 & 24.59 & 100.00 & 0.00 & 0.80 \\
\hline A2 $10-30$ & 1.99 & 35.18 & 15.07 & 20.11 & 70.00 & 30.00 & 0.75 \\
\hline Bw1 30- 35 & 1.21 & 34.13 & 15.87 & 18.26 & 65.00 & 35.00 & 0.87 \\
\hline Bw2 35- 45 & 0.91 & 31.87 & 14.29 & 17.58 & 0 & 100.00 & 0.81 \\
\hline C1 55-70 & 0.67 & 37.31 & 17.91 & 19.4 & 0 & 100.00 & 0.92 \\
\hline \multicolumn{8}{|c|}{ Profile 5. Luvic Planosol - Hadjiyanakiev et. al. (1981) (village of Zlatosel - $350 \mathrm{~m}$ ) } \\
\hline AE $0-10$ & 0.70 & 48.39 & 20.77 & 27.65 & 83.08 & 16.95 & 0.75 \\
\hline E $10-28$ & 0.28 & 52.20 & 18.62 & 33.92 & 100.00 & 0.00 & 0.56 \\
\hline Btg1 40-55 & 0.18 & 53.46 & 21.76 & 33.70 & 13.59 & 84.41 & 0.68 \\
\hline Btg1 55-73 & 0.18 & 52.22 & 5.00 & 44.22 & 0.00 & 100 & 0.1 \\
\hline Btg1 73-96 & 0.20 & 46.76 & 4.83 & 41.92 & 0.00 & 100 & 0.12 \\
\hline \multicolumn{8}{|c|}{ Prfofie 6. Haplic Luvisol - Shishkov et al. (2015) (Hisarya , $350 \mathrm{~m}$ ) } \\
\hline Ah $0-20$ & 0.86 & 36.05 & 14.44 & 0.94 & 0.0 & 100.0 & 0.94 \\
\hline Bt1 $20-40$ & 0.48 & 29.17 & 25.00 & 6.00 & 0.0 & 100.0 & 6.00 \\
\hline Bt2 $40-60$ & 0.36 & 38.89 & 0 & - & 0.0 & 0.00 & - \\
\hline Bt3 $60-80$ & 0.31 & 32.26 & 0 & - & 0.0 & 0.00 & - \\
\hline BC $80-100$ & 0.21 & 38.09 & 0 & - & 0.0 & 0.00 & - \\
\hline
\end{tabular}

Because of forest vegetation biological activity is intensive in the topsoil. Humus accumulation occurs in the horizon beneath the litter. The dark brown color is due to the presence of Fulvic acids and/or brown colored Humic acids (Shishkov et al., 2014). The content of organic matter sharply decreases with the increasing of 
soil depth (Table 2). Humus content in surface could be very high in pre-alpine area and a few times lower in deciduous forest $400-800 \mathrm{~m}$. This is the reason that the organic carbon content varies widely. Typically in soils developed under forest the Fulvic acids prevail over Humic acids (Profile 4), the type of humus is humic-Fulvic and the ratio $\mathrm{Ch} / \mathrm{Cf}$ is $0.5-1$. The degree of humification is moderately low and the Humic acids are "free" or bound with $\mathrm{R}_{2} \mathrm{O}_{3}$ (Filcheva, 2015; Hristov et al., 2016) in the surface horizon.

In the lower parts of the mountains, mainly under deciduous forest Planosols and Luvisols are spread. Planosols have one of the lowest content of organic matter in the country (Artinova, 1978). Soil formation proceeds under the influence of acid plant residues from forests and seasonal waterlogging caused by the surface stagnating waters. Soil formation consisted of some pseudo-gley formation processes as, waterlogging, leaching, and clay formation (Koinov et al., 1998). Average organic matter content is about 1 $1.5 \%$ in cultivated soils, up to $2 \%$ in forest soils. The organic matter stocks in the one-meter layer do not exceeds 2 t.ha-1 $^{-1}$ uncultivated lands and 1-1.5 t.ha-1 in agricultural areas (Koinov et al., 1998). Fulvic acids (Cf) are presented in significant quantities, which determine the very low $\mathrm{Ch} / \mathrm{Cf}$ ratio. The humus type is Humic-Fulvic or Fulvic along the soil profile depth (Ch/Cf 1-0.5 or $<0.5$ ).

Most wide spread soil type of Bulgaria is Luvisol with area of $33 \%$ from the territory of the state. These soils usually occupy uplands on the plains, elevated sites in the valleys, and the foot slopes of mountains with elevation below $700 \mathrm{~m}$. Luvisols have shallow profile about $90 \mathrm{~cm}$, and typical for them clay enriched luvic horizon. The content of carbon is low in the surface horizon about $0.7-1.5 \%$ and decreases sharply in depth. The type of humus is Fulvic - Humic (Ch/Cf $1.5-1.0)$ and under forest usually is Humic - Fulvic (1.0 0.5). Dilkova et al. (1998) found that the ratios $\mathrm{Ch} / \mathrm{Cf}$ of surface waterlogged layers $\left(A, A_{1} A_{2}, A_{21}\right)$ of Planosols and Luvisols increase with degree of surface waterlogging of these soils. The degree of humification is high in A horizon (about 25 \%) (Filcheva, 2015).

\section{Mesic - Ustic regime.}

Mesic - Ustic zone covers the middle hilly part of Danubian plain and some high fields, hills, and low mountains in South Bulgaria. Main soil types are Phaeozems and Chernozems in Danubian plain and Luvisols in the south. Phaeozems and Chernozems are the most productive and fertile soil in all over the world. The so called "Corn belt" of Europe is crossing at that longitude.

Table 3. Organic matter of Phaeozem, Haplic Chernozme and Luvisol with Mesic - Ustic regime $*^{*}-\%$ of the total organic carbon, ${ }^{* *}$ - $\%$ of the total HA).

\begin{tabular}{|c|c|c|c|c|c|c|c|}
\hline \multirow{2}{*}{$\begin{array}{l}\text { Horizon, } \\
\text { Depth cm }\end{array}$} & \multirow{2}{*}{$\begin{array}{l}\text { Total } \\
\text { Carbon } \\
\text { (C) \% }\end{array}$} & \multicolumn{3}{|c|}{$\begin{array}{c}\text { Org. Carbon } \% \text {-Extracted with } \\
0.1 \mathrm{M} \mathrm{Na} \mathrm{P}_{2} \mathrm{O}_{7}+0.1 \mathrm{M} \mathrm{NaOH}\end{array}$} & \multirow{2}{*}{$\begin{array}{c}\text { Free Humic } \\
\text { acids } \% \text { or } \\
\text { bound with } \\
\mathrm{R}_{2} \mathrm{O}_{3}, * *\end{array}$} & \multirow{2}{*}{$\begin{array}{c}\text { Humic acids } \\
\% \text { bound } \\
\text { with Calcium } \\
\left(\mathrm{Ca}^{+2}\right), * *\end{array}$} & \multirow[t]{2}{*}{$\mathrm{Ch} / \mathrm{Cf}$} \\
\hline & & $\begin{array}{l}\text { Total } \\
(\%), *\end{array}$ & $\begin{array}{l}\text { Humic acids } \\
(\%),{ }^{*}\end{array}$ & $\begin{array}{c}\text { Fulvic acids } \\
(\%),{ }^{*}\end{array}$ & & & \\
\hline \multicolumn{8}{|c|}{ Profile 7. Luvic Phaeozem - Hadjiyanakiev et. al. (1981) (v. of Grivitza 256m.) } \\
\hline Ah $0-12$ & 2.62 & 50.22 & 20.09 & 30.12 & 38.73 & 61.27 & 0.66 \\
\hline A2 $12-35$ & 0.78 & 61.04 & 24.05 & 36.98 & 12.52 & 87.48 & 0.65 \\
\hline ABt $35-65$ & 0.8 & 31.98 & 10.03 & 21.95 & 0 & 100 & 0.45 \\
\hline Bt1 $65-95$ & 0.4 & 53.54 & 37.97 & 21.56 & 0 & 100 & 1.48 \\
\hline Bt2 $95-130$ & 0.25 & 55.59 & 20.71 & 35.28 & 0 & 100 & 0.58 \\
\hline Ck 130 - & 0.29 & 34.53 & 14.71 & 19.81 & 0 & 100 & 0.74 \\
\hline \multicolumn{8}{|c|}{ Profile 8. Haplic Chernozem - Artinova (1989) (Dobrich, 240m ) } \\
\hline A1 $0-17$ & 2.28 & 43.4 & 23.6 & 19.8 & 24.6 & 75.4 & 1.2 \\
\hline A2 $17-37$ & 1.16 & 40.1 & 22.4 & 17.7 & 0 & 100 & 1.3 \\
\hline AB $37-60$ & 0.95 & 47.6 & 27.0 & 20.6 & 0 & 100 & 1.3 \\
\hline AB $60-83$ & 0.58 & 49.8 & 29.0 & 21.0 & 0 & 100 & 1.4 \\
\hline BC 83-95 & 0.52 & 49.2 & 29.2 & 20.0 & 0 & 100 & 1.5 \\
\hline \multicolumn{8}{|c|}{ Profile 9. Haplic Luvisol - Hadjiyanakiev et. al. (1981) (v. of Bohot 256m.) } \\
\hline Ah $0-15$ & 1.61 & 48.9 & 21.8 & 27.1 & 75 & 25 & 0.8 \\
\hline A1 $15-40$ & 0.92 & 43.5 & 17.1 & 26.4 & 75 & 25 & 0.65 \\
\hline Bt1 $40-55$ & 0.49 & 53.5 & 12.1 & 41.4 & 67 & 33 & 0.3 \\
\hline
\end{tabular}

Phaeozems in North Bulgaria occupy about 200000 ha and they are located on the North-Western part and Ludogorie plateau or approximately $1.79 \%$ of the entire territory of the country. The typical distinguishing features are humus accumulation, deep carbonate leaching (below 120-250 cm), low differentiation of clay, low compaction pronounce, and high biological activity, especially of earthworms (Shishkov et al. 2014). 
Usually soil organic matter content in (A) horizon is 2.0-4.5\%. Humic acids prevail over Fulvic acids and they are bounded with calcium whch makes them stable (Table 3, Profile 7). The stocks of organic matter in a $100 \mathrm{~cm}$ layer is 200-300 tha- ${ }^{-1}$, however, it is about 200-250 t.ha-1 in the arable lands (Filcheva et al. 2002). These soils are characterized with high degree of humification and the type of humus in surface horizons is Humic - Fulvic $(\mathrm{Ch} / \mathrm{Cf} 1.0-0.5)$ or even Fulvic $(\mathrm{Ch} / \mathrm{Cf}<0.5)$ in depth. Manly in $(\mathrm{A})$ horizon there are some "free" and more Humic acids bound with calcium. Other most valuable (fertile) soils in Bulgaria are Chernozems. They are spread over the larger part of the Danubian Plain, Dobrudja and Ludogorie plateau. Chernozems occupy about 2250000 ha or $20 \%$ of the territory of the entire country (Koinov et al., 1998). They are formed in climatic zones with annual precipitation of 450-600 mm, with maximum of precipitation in spring and early summer, cold winters, and relatively hot summers. In the colder areas of these climatic zones, natural grass vegetation develops on soil profiles. Carbonates may accumulate below this layer because of limited downward percolation of calcium salts and in Bulgaria they are developed over loess parent material. Chernozems are characterized by a surface layer that is rich in humus and in available calcium ions bound to soil particles, resulting in a well-aggregated structure with abundant natural grass vegetation. In the south part of Danibian plain Leached Chernozems (Haplic Chernozems) are the most typical soil type with territory of about 850000 ha. The thickness of the Leached Chernozem is $80-120 \mathrm{~cm}$, and the thickness of the humus horizon $(\mathrm{A}+\mathrm{AB})$ is $50-80 \mathrm{~cm}$. The organic carbon content is from 2.3 to 0.5 $\%$ at the upper part of the humus horizon and gradually decreases downwards (Table 3, Profile 8). Soil organic matter stocks in whole profile are about 200 thha $^{-1}$ and 80 t.ha-1 $^{-1}$ in A horizon (Artinova, 2014). The Humic acids prevail over Fulvic acids (Ch/Cf 1.0 - 1.5) and the type of humus is Fulvic-Humic. Usually the Humic acids are bound with calcium.

In the southern part of Danubian plain mainly under forest vegetation Luvisols are also spread.

The Luvisols (Grey forest soils, Koinov et al., 1963; Penkov et al., 1992) from north Bulgaria occupy the area of 1.6 million ha or $14.5 \%$ of the state (Koinov et al., 1998). These soils are formed on loesslike materials, carbonate moraines, and other parent materials that are usually rich in calcium and an elutriate water regime. The movement of humates of potassium from the top horizons to deeper ones and precipitation on the surface of structural partings in the form of humus films are especially typical of gray forest soils. The soil organic matter content is about $1.5-2 \%$ in cultivated lands and $2-3 \%$ in the natural soils. The humus stocks are $180-250$ tha $^{-1}$ in $1 \mathrm{~m}$ depth. The type of humus is Humic - Fulvic (Ch/Ch $\left.1.0-0.5\right)$ which is typical for Luvisols and $75-67 \%$ of the Humic acids are "free" or bound with $\mathrm{R}_{2} \mathrm{O}_{3}$ (Table 3, Profile 9).

\section{Mesic - Xeric regime.}

The lower parts of Danubian plain and the bigger part of Upper Thrace Valley have Mesic- Xeric soil temperature and moisture regime. This area is spread over the watersheds of the biggest rivers in Bulgaria, Danube and Maritsa, where the main soil types are Fluvisols, Vertisols and Calcic Chernozems (Kastanozems).

Calcic Chernozems are distributed immediately to the south of the Danube River, mainly in the Lom Svishtov soil- geographical province on calcareous loess. They occupy about 5 million ha. WRB (2014) has allowed that some soils that have a Mollic horizon can be referred to Kastanozems in semi-arid climate conditions. There is discussion about whether Kastanozens can be morphologically identified where Calcic Chernozems occur (Shishkov, 1998). Compared with other Chernozems generally they are shallow and the organic carbon content is lower (Table 4, Profile 10). Content of humus varies from 2.0 to $4.2 \%$ on the upper part of humus horizon, decreases by 18-20 \% compared to uncultivated soils and in recent years is it range from 1.5 to $2.1 \%$. Organic matter stocks are from 250 to 400 t.ha-1 to a depth of $100 \mathrm{~cm}$ (Filcheva et al., 2002). The type of humus is Fulvic - Humic or Humic (Ch/Cf $1.0-1.5$ or $>1.5$ ). The Humic acids are stable and $100 \%$ bound with calcium.

Vertisols are distributed mainly in southern Bulgaria and occupies 600000 ha or about $5.34 \%$ of the entire country's territory (Koinov et al., 1998). They are most commonly formed in warm, subhumid or semi-arid climates, where the natural vegetation is predominantly grass. Two climatic regions are associated with the distribution of Vertisols in Bulgaria. The first is confined to the transitional continental climatic zone with Mediterranean influence in the Thracian Lowland. The second region is confined to the transitional continental zone in Western Bulgaria (Shishkov et al., 2014). Vertisols are usually very dark in color, with widely variable organic matter content $(1-6 \%)$. They typically form on Calcium and Magnesium rich 
materials such as limestone, basalt, or in areas of topographic depressions that collect these elements leached from uplands.

Table 4. Organic matter of Calcic Chernozme, Vertisol and Fluvisol with Mesic - Xeric regime $(*$ - $\%$ of the total organic carbon, ${ }^{* *}-\%$ of the total HA).

\begin{tabular}{|c|c|c|c|c|c|c|c|}
\hline \multirow{2}{*}{$\begin{array}{l}\text { Horizon, } \\
\text { Depth cm }\end{array}$} & \multirow{2}{*}{$\begin{array}{c}\text { Total } \\
\text { Carbon } \\
\text { (C) \% }\end{array}$} & \multicolumn{3}{|c|}{$\begin{array}{c}\text { Org. Carbon } \% \text {-Extracted with } \\
0.1 \mathrm{M} \mathrm{Na}{ }_{4} \mathrm{P}_{2} \mathrm{O}_{7}+0.1 \mathrm{M} \mathrm{NaOH}\end{array}$} & \multirow{2}{*}{$\begin{array}{c}\text { Free Humic } \\
\text { acids \% or } \\
\text { bound with } \\
\mathrm{R}_{2} \mathrm{O}_{3}, * *\end{array}$} & \multirow{2}{*}{$\begin{array}{c}\text { Humic acids \% } \\
\text { bound with } \\
\text { Calcium } \\
(\mathrm{Ca}+2), * *\end{array}$} & \multirow[t]{2}{*}{$\mathrm{Ch} / \mathrm{Cf}$} \\
\hline & & $\begin{array}{l}\text { Total } \\
(\%), *\end{array}$ & $\begin{array}{l}\text { Humic acids } \\
\quad(\%),{ }^{*}\end{array}$ & $\begin{array}{l}\text { Fulvic acids } \\
\quad(\%),{ }^{*}\end{array}$ & & & \\
\hline \multicolumn{8}{|c|}{ Profile 10. Calcic Chernozem - Artinova (1989) (dis. V. Turnovo, 150m ) } \\
\hline Ak $0-23$ & 1.93 & 25.1 & 14.7 & 10.4 & 0 & 100 & 1.4 \\
\hline Ak2 23 -38 & 1.21 & 24.5 & 15.3 & 9.2 & 0 & 100 & 1.6 \\
\hline ABk $38-60$ & 0.87 & 30.1 & 16.4 & 13.7 & 0 & 100 & 1.2 \\
\hline BCk $60-84$ & 0.55 & 26.7 & 13.6 & 13.1 & 0 & 100 & 1.0 \\
\hline \multicolumn{8}{|c|}{ Profile 11. Haplic Vertisol - Teoharov et al. (2007) ( v. Choba, Plovdiv, 180m) } \\
\hline Ap $0-22$ & 2.44 & 17.37 & 13.37 & 3.99 & 0 & 100 & 3.35 \\
\hline AB $44-72$ & 0.73 & 26.17 & 24.89 & 1.28 & 0 & 100 & 19.48 \\
\hline Bk $72-105$ & 1.03 & 16.11 & 12.61 & 3.50 & 0 & 100 & 3.6 \\
\hline BCk 105-135 & 0.48 & 19.09 & 10.52 & 8.56 & 0 & 100 & 1.23 \\
\hline \multicolumn{8}{|c|}{ Profile 12. Haplic Fluvisol - Mihailov (1988) ( town of Belene, $25 \mathrm{~m}$ ) } \\
\hline Ap $0-25$ & 0.54 & 46.3 & 29.63 & 16.67 & 0 & 100 & 1.78 \\
\hline C1 $25-50$ & 0.49 & 44.9 & 32.65 & 12.24 & 0 & 100 & 2.67 \\
\hline $\mathrm{C} 250-70$ & 0.38 & 42.11 & 26.35 & 15.79 & 0 & 100 & 1.67 \\
\hline
\end{tabular}

Humus stocks for uncultivated lands in surface horizon is about 115 tha $^{-1}$ and 313 t.ha-1 $^{-1}$ for whole profile (Artinova, 2014), the type of humus is Humic or Fulvic-Humic (Ch/Cf $>1.5$ or $1.0-1.5$ ). Humic acids are bound with calcium (100\%) and the degree of humification is very high, with high condensation of aromatic nuclei (Filcheva, 2015).

Fluvisols could be found on alluvial plains, river fans, valleys and tidal marshes on all parts of Bulgaria and in all climatic zones. Under natural conditions periodical flooding is fairly common. In Bulgaria typical areas of occurrence are in the Thracian Lowland and Danubian plain. They are occupy $6.53 \%$ of the state or 730000 ha. Fluvisols have a clear evidence of stratification. Soil horizons are weakly developed, but a distinct topsoil horizon may be present. These soils exhibit a stratified profile that reflects their depositional history or an irregular layering of humus and mineral sediments in which the content of organic carbon decreases with depth. Fluvisols are characterized by a low stock of nutrient elements (Shishkov et al., 2014). Soils are poor in organic carbon content under $1 \%$ (Profile 12). The type of humus is Humic (Ch/Cf $>1.5$ ). Humic acids are bound with calcium (100\%) and have high condensation of aromatic nuclei and the degree of humification is very high.

\section{Thermic - Xeric regime}

The driest and warmest pedoclimatic regime in Bulgaria with subtropical influence occupies the south border parts of the state. The climate is formed under the influence of transformed tropical air masses and those of the temperate latitudes. The average annual temperature is $13^{\circ} \mathrm{C}-13,5^{\circ} \mathrm{C}$. Rainfall regime autumn-winter maximum and summer-minimum - is typical for Mediterranean climate. Dry period is not so long and the maximum and minimum rainfall is less presented. Annual rainfall amounts between 500-600 $\mathrm{mm}$. The main soil types for these regions are Vertisols, Luvisols, Cambisols, Regosols and Leptosols.

Vertisols in that region have similar properties as those with Mesic- Xeric temperature and moisture regime.

Cinnamonic forest soil of South Bulgaria is the main soil type (Koinov et al., 1963). In the geographic distribution, these soils are found in elevated areas, where the level of ground water is of considerable depth. Meadow soil varieties occur near the river valleys and old terraces (Shishkov et al., 2014). According WRB (2014) Cinnamonic forest soil could be classified as Cambisols with cambic horizon, Luvisols if they have argic horizon and even Leptosols when they are shallow. Chromic Cambisols and Chormic Luvisols are spread over calcareous materials and they occupy area about 12000 ha. The content of organic carbon in A horizon range usually from $0.9 \%$ to $1.35 \%$. The organic matter stocks vary 72 t.ha $^{-1}$, in the surface horizon to 144 t.ha $^{-1}$ for the whole profile (Artinova, 2014). The Humic acids in profile 14 totally dominate over Fulvic acids and the type of humus is humic. Expectable the degree of humification is high and Humic acids are $100 \%$ bound with calcium. 
Table 5. Organic matter of Vertisols, Cambisols and Regosols with Thermic - Xeric regime ${ }^{*}-\%$ of the total organic carbon, $* *$ - $\%$ of the total HA).

\begin{tabular}{|c|c|c|c|c|c|c|c|}
\hline \multirow{2}{*}{$\begin{array}{l}\text { Horizon, } \\
\text { Depth cm }\end{array}$} & \multirow{2}{*}{$\begin{array}{l}\text { Total } \\
\text { Carbon } \\
\text { (C) \% }\end{array}$} & \multicolumn{3}{|c|}{$\begin{array}{l}\text { Org. Carbon } \% \text {-Extracted with } \\
0.1 \mathrm{M} \mathrm{Na}{ }_{4} \mathrm{P}_{2} \mathrm{O}_{7}+0.1 \mathrm{M} \mathrm{NaOH}\end{array}$} & \multirow{2}{*}{$\begin{array}{c}\text { Free Humic } \\
\text { acids \% or } \\
\text { bound with } \\
\mathrm{R}_{2} \mathrm{O}_{3}, * *\end{array}$} & \multirow{2}{*}{$\begin{array}{l}\text { Humic acids } \\
\% \text { bound } \\
\text { with Calcium } \\
\left(\mathrm{Ca}^{+2}\right), * *\end{array}$} & \multirow[t]{2}{*}{$\mathrm{Ch} / \mathrm{Cf}$} \\
\hline & & $\begin{array}{l}\text { Total } \\
(\%), *\end{array}$ & $\begin{array}{l}\text { Humic acids } \\
(\%),{ }^{*}\end{array}$ & $\begin{array}{c}\text { Fulvic acids } \\
(\%), *\end{array}$ & & & \\
\hline \multicolumn{8}{|c|}{ Profile 13. Haplic Vertisol - Artinova (2014), (v. Yastrebovo, S. Zagora, 168m) } \\
\hline A1 $0-20$ & 2.79 & 48.6 & 28.8 & 19.8 & 0 & 100 & 1.50 \\
\hline A2 $20-39$ & 1.86 & 46.8 & 28.4 & 18.4 & 0 & 100 & 1.50 \\
\hline A3 $39-65$ & 1.10 & 46.8 & 29.4 & 17.4 & 0 & 100 & 1.70 \\
\hline AC $65-89$ & 0.86 & 44.3 & 28.1 & 16.2 & 0 & 100 & 1.7 \\
\hline C1 $89-106$ & 0.28 & 40.0 & 19.1 & 20.9 & 0 & 100 & 0.9 \\
\hline \multicolumn{8}{|c|}{ Profile 14. Calcaric Cambisol - Dialo (1995), (v. Sklave, dis. Blagoevgrad, 183m) } \\
\hline Akf $0-4$ & 0.62 & 43.55 & 37.09 & 0.04 & 0 & 100 & 5.75 \\
\hline Ak 4- 15 & 0.46 & 26.8 & 26.08 & 0.0 & 0 & 100 & - \\
\hline Bwk 1540 & 0.16 & 25.0 & 0.0 & 0.04 & 0 & 0 & - \\
\hline Ck 4060 & 0.11 & - & - & - & - & - & - \\
\hline \multicolumn{8}{|c|}{ Profile 15. Calcaric Regosol - Teoharov et al. (2007), (v. Vinogradi, dis. Blagoevgrad, 391m) } \\
\hline Ak $0-17$ & 0.51 & 39.22 & 17.65 & 21.57 & 0 & 100 & 0.82 \\
\hline ACk $17-30$ & 0.21 & 42.86 & 0 & 42.86 & - & - & \\
\hline $\mathrm{Ck} 30-50$ & 0.09 & 33.33 & 0 & 33.33 & - & - & \\
\hline
\end{tabular}

Regosols are spread in the valley of rivers and in the downslopes of the mountains in South Bulgaria. They are extensive in eroding lands, in particular in arid and semi-arid areas and in mountain regions. The area of Regosols has increased with time, mainly due to improper use of the land. Erosion of the soil is a common occurrence in southern hilly regions. Regosols are spread mainly over steep slopes, which is the reason for bad soil water regime. As a result of soil erosion the total amount nutrients is reduced and organic carbon content is low. The quantity of organic carbon in the surface horizons is under $0.60 \%$, and decreases in depth (profile 15). Usually Humic acids are bound $100 \%$ with calcium. Soil organic matter composition shows that Humic and Fulvic acids are almost equal. The ratio $\mathrm{Ch} / \mathrm{Cf}$ in the surface horizon is 0.82 , which indicates the Humic-Fulvic type of humus.

\section{Conclusion}

Grouping soil types in five soil temperature and moisture regimes shows that there are similarities in soil carbon content and composition. Soils developed under more cool and moist condition accumulate more organic carbon especially soils with Cryic - Udic regime where carbon stocks is about 255 tha $^{-1}$ in the surface horizon. Contrary soils developed under Thermic - Xeric regime have the lowest organic carbon content. The same is with "free" humic acids bound with $\mathrm{R}_{2} \mathrm{O}_{3}$, which are more in soils with more cool and wet pedoclimate. Soils with dry Mesic - Xeric and Thermic- Xeric regime are $100 \%$ bound with calcium. The type of humus depends mainly from different vegetation over soils. However soils with dry and warm regime have Humic or Fulvic-Humic type of humus (Ch/Cf $>1.5$ or $1.0-1.5$ ). Soils with Cryic - Udic and Mesic - Udic regime usually have Fulvic or Humic - Fulvic type of humus $(\mathrm{Ch} / \mathrm{Cf}<0.5$ or $1.0-0.5)$.

\section{References}

Andreeva, N., 2014, Geochemical and mineralogical characteristics of soils from the highest parts of Vitosha mountain and the relationship with the soil-forming substrate. St. Climent Ohridski University, Sofia, Bulgaria. PhD thesis. [in Bulgarian].

Artinova, N., 1978. Organic Matter in Pseudopodzolic soils of Bulgaria. Agricultural Institute, "V. Kolarov", Plovdiv, Bulgaria. PhD thesis. $178 \mathrm{p}$. [in Bulgarian].

Artinova, N., Gurov G., 1985. Organic matter in some mountain-meadow and brown forest soils. International meeting on classification and management of soils in mountain regions, 25 - 29 September 1984, Sofia, pp 203- 210 [in Bulgarian]

Artinova, N., 1989. Humus content of uncultivated Chernozems in Bulgaria. Forth National Conference of Soil Science, 28 - 30 May, Sofia, Bulgaria. pp. 95-100 [in Bulgarian].

Artinova, N., 2014. Humus status of soils in Bulgaria. In: Soil Organic Matter and Fertility of Soils in Bulgaria. Bulgarian Humic Substances Society. p. 29 - 74 [in Bulgarian].

Boyadjiev, T., 1989, Temperature and water regime of Bulgarian soils. Forth National Conference of Soil Science. 28 30 May, Sofia, Bulgaria. pp. 207 - 213 [in Bulgarian].

Costantini, E.A.C., Fantappie', M., L'Abate, G., 2013, Climate and Pedoclimate of Italy. In: Soils of Italy. Costantini, E. A. C., Dazzi, C. (Eds.). Springer, pp.19-38. 
Dialo, A., 1995, Basic genetic process in soils in some from hilly-mountaious territories of Southwest Bulgaria. ISAPP "N. Poushkarov". PhD thesis, 144 p. [in Bulgarian].

Dilkova, R., Filcheva, E., Kerchev, G., Kercheva, M., 1998. Humus peculiarities of the virgin surface waterlogged soils. In: $16^{\text {th }}$ World Congress of Soil Science, 20-26 August 1998, Montpelier, France.

Dimitrov E., 2014. Variation in the physical properties of soil at different spatial and temporal scales. ISSAPP "N. Poushkarov" Department of Soil Physics, PhD thesis, 154 p. [in Bulgarian].

FA0. 2006. Guidelines for soil description. $4^{\text {th }}$ edition. Food and Agriculture Organization of the United Nations, Rome, Italy. 97 p.

Filcheva, E., Rousseva, S., Kulikov, A., Nedyalkov, S., Chernogorova, T., 2002. Organic carbon stocks in soils of Bulgaria. In: Agricultural practices and policies for carbon sequestration in soils. Kimble, J.M., Lal, R., Follett, R.F. (Eds.), Lewis Publishers, CRC Press LLC, New York, USA. pp 471-476.

Filcheva, E.G., Tsadilas, C.D., 2002. Influence of clinoptilolite and compost on soil properties. Communications in Soil Science and Plant Analysis 33 (3-4): 595-607.

Filcheva, E., 2014. Humus development, content of the soil organic matter and carbon stocks in different soil groups, pp. 88 - 106. In: Soil organic matter and fertility of soils in Bulgaria. Bulgarian Humic Substances Society. 475 p. [in Bulgarian].

Flicheva, E., 2015. Characteristics of soil organic matter of Bulgarian soils. LAP Lambert Academic Publishing, 184 p.

Geography of Bulgaria, 2002. Physical and social-economical geography. Bulgarian Academy of Sciences, Sofia, Bulgaria. 760 p. [in Bulgarian].

Hadgiyanakiev, A., Angelov, E., 1981. Analytical data of soil profiles study tour. Second International Meeting on Soil Classification, Institute of Soil Science "N. Poushkarov", Sofia, Bulgaria. 64 p.

Hristov, B., Filcheva, E., Ivanov, P., 2016. Organic matter content and composition of soils with stagnic properties from Bulgaria. Bulgarian Journal of Soil Science 1(1): 26-32.

Kirschbaum, M.U.F., 1995. The temperature dependence of soil organic matter decomposition, and the effect of global warming on soil organic C storage. Soil Biology and Biochemistry 27(6): 753-760.

Krastanov, S., Filcheva, E., Rousseva, S., Raichev, T., Dimitrov, I., Pachev, I., 2003. Tendencies and perspectives of the research on humic substances. Ecology and Future 2(3-4): 11 - 18.

Koinov, V., H. Trashliev, N. Ninov, M. Jolevski, T. Boyadjiev. 1963. Classification and systematic of soils in Bulgaria. In: Soils of South-Eastern Europe. Proceedings of the international symposium of soil science, June 1963, Sofia. Bulgarian Academy of Sciences Press, Sofia, Bulgaria. p 231-246. [in Russian]

Koinov, V., Kabakchiev, I., Boneva, K., 1998. Atlas of the soils in Bulgaria. Zemizdat, Sofia, Bulgaria [in Bulgarian].

Kolchakov, I., 1994. Soil Project CESD-Communataree and N. Poushkarov Institute of Soil Science and Agroecology, N 392 EHL/SW). Soil Geographical Data Base of Europe at Scale 1:1,000,000 version 3.27, 20/04/1998.

Kononova M., 1966. Soil Organic Matter. Its Nature, its role in soil formation and in soil fertility. $2^{\text {nd }}$ Edition. Pergamon Press, Oxford. UK., 544 p.

Newhall, F., 1972. Calculation of soil moisture regimes from the climatic record, Revision 4. USDA Soil Conservation Service: Washington DC, USA.

Mihailov, M., 1988. Genesis, diagnostic and classifications of the soils develop over sands in Danubian palin. Institute of Soil Science "N. Poushkarov", Sofia, Bulgaria. PhD thesis. 169 p. [in Bulgarian].

Orlov, D.S., 1985. Soil chemistry. Moscow State University, Moscow, Russia. 376 p. [in Russian].

Penkov, M., Donov, V.D., Boyadjiev, T., Andonov, T., Ninov, N., Yolevski, M., Andonov, G., Gencheva, S., 1992. Classification and diagnostic of Bulgarian soils related with land reform. Zemizdat, Sofia, Bulgaria. 151 p. [in Bulgarian].

Shnitzer, M., Khan, S.U., 1972. Humic substances in the environment. Marcel Dekker, New York, USA. 327p.

Shishkov, T., 1998. An idea concerning genesis and classification of soils from northern part of Danube Valley in Bulgaria. 16 $6^{\text {th }}$ World Congress of Soil Science, 20-26 August 1998, Montpelier, France.

Shishkov, T., Kolev, N. 2014 . The Soils of Bulgaria, World Soils Book Series, Springer, 208 p.

Shishkov, T., Hristov, B., Kolchakov, V., Hristova, M., Anachkov, K., 2015. Soil field guide. Ambrozia NT., 16 p.

Smith P., Fang, C.. Dawson, J.J.C., Moncrieff, J.B., 2008. Impact of global warming on soil organic carbon. Advances in Agronomy 97:1-43.

Soil Survey Staff, 1999. Soil taxonomy. $2^{\text {nd }}$ edition, United States Department of Agriculture (USDA), Natural Resources Conservation Service (NRCS), Agricultural Handbook, No. 436. Washington DC., USA. 886 p.

Soil Survey Staff. 2010. Keys to soil taxonomy. 11 th edition, United States Department of Agriculture (USDA), Natural Resources Conservation Service (NRCS), Washington DC., USA. 338 p.

Stevenson, F.J., 1994. Humus chemistry: Genesis, composition, reaction. John Wiley, New York, USA. 496 p.

Subev, A., Stanev, S., 1963, Climatic regions of Bulgaria and their climate. Zemizdat. Sofia, Bulgaria. [in Bulgarian].

Teoharov, M., Ilieva, R., Nedyalkov, S., Popova, Z., Hristov, B., 2007. Soil Guide. 60 Years Institute "N. Poushkarov" of Soil Science, Sofia, Bulgaria. 90 p. [in Bulgarian].

WRB, 2014 - IUSS Working Group WRB. 2014. World reference base for soil resources 2014. International soil classification system for naming soils and creating legends for soil maps. World Soil Resources Reports No. 106. FAO, Rome, Italy. 